\title{
Tooth Not Erupted
}

National Cancer Institute

\section{Source}

National Cancer Institute. Tooth Not Erupted. NCI Thesaurus. Code C124565.

A finding that a tooth has not emerged. 